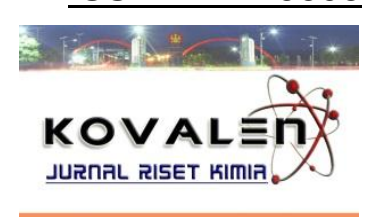

\title{
KAJIAN KADAR FENOLAT DAN MUTU ORGANOLEPTIK BUBUR INSTAN DARI UBI BANGGAI JENIS BAKU MAKULOLONG (Discoreabulbifera var celebica bukill) DAN BAKU PUKUS (Discorea of alata)
}

\section{[Study of Phenolate Content and Organoleptic Quality of Porridge Instant from Baku Makulolong (Discoreabulbifera var celebica Bukill) and Baku Pukus (Discorea of alata) Species of Banggai Yam]}

\author{
Sri Adeningsih ${ }^{1}$, Syaiful Bahri ${ }^{{ }^{*}}$, Nurhaeni ${ }^{1}$ \\ 1) Jurusan Kimia Fakultas MIPA, Universitas Tadulako \\ Diterima 24 Agustus 2015, Diterima 16 September 2015
}

\begin{abstract}
Study about "Studies levels of phenolics and organoleptic quality of Banggai Yam Instan Porridge species Baku Makulolong (DiscoreaBulbifera Var Celebica Bukill) and Baku Pukus (Discorea Of Alata.)" has been done. The aim of this research was to know the phenolic content of potato proud content of both the yam before and after becoming an instant porridge and to know its organoleptic quality. The result showed that when Baku Makulolong have high levels of phenolic wet (yield galtinasi) at 2.381\%, wet (Yield glatinasi) Baku Pukus have high levels of phenolic $2.162 \%$. Whereas dried have high levels of phenolic currently $1.638 \%$ and $1.395 \%$.Contained levels of phenolics in Baku Makulolong yam porridge $1.852 \%$ and phenolics content contained on Baku Pukus yam porridge $1.671 \%$. Organoleptic quality of the test results on the parameters of taste, aroma and texture show that there is no real difference between instant porridge yam instant Baku Pukus with Baku Makulolong yam porridge. While the color parameters showed a significant difference between the color of Baku Pukus instant porridge with Baku Makulolong instant porridge.
\end{abstract}

Keywords : phenolics, organoleptic quality, Banggai yam

\begin{abstract}
ABSTRAK
Penelitian mengenai "Kajian Kadar Fenolat dan Mutu Organoleptik Bubur Instan dari Ubi Banggai Jenis Baku Makulolong (DiscoreaBulbifera Var Celebica Bukill) Dan Baku Pukus (Discorea Of Alata.)telah dilakukan. Penelitian ini bertujuan untuk mengetahui kadar fenolat kedua jenis ubi Banggai tersebut sebelum dan sesudah diolah menjadi bubur instan dan mutu organoleptiknya. Hasil penelitian diperoleh adalahBaku Makulolong basah (hasil glatinasi) memiliki kadar fenolat 2,381\% dan Baku Pukus basah (hasil glatinasi) memiliki kadar fenolat 2,162 \%. Sedangkan saat kering (hasil glatinasi) memiliki kadar fenolat 1,638 \% dan 1,395 \%. Kadar fenolat yang terkandung pada buburBaku makulolong 1,852 \% dan kadar fenolat yang terkandung pada bubur Baku Pukus 1,671 \%. Dari hasil uji mutu organoleptik pada parameter rasa, aroma dan tekstur menunjukkan bahwa tidak ada perbedaan yang nyata antara bubur instan Baku Pukus dengan bubur instan Baku Makulolong. Sedangkanpada parameterwarnamenunjukkanadanya perbedaan nyata antara warna bubur instan Baku Pukus dengan bubur instan Baku Makulolong.
\end{abstract}

Kata Kunci : Fenolat, mutu organoleptik, bubur instan, ubi Banggai 


\section{LATAR BELAKANG}

Tingkat ketergantungan masyarakat Indonesia terhadap konsumsi beras sebagai makanan pokok telah mencapai tingkat yang sangat tinggi.Beras telah menjadi pemasok utama karbohidrat bagi mayoritas bahkanhampir seluruh masyarakat Indonesia.Ketergantungan masyarakat Indonesiaterhadap beras telah menjadi sebuah masalah pangan yang berkelanjutan.Pemerintah bersama para peneliti kini berupaya mencarisumbersumber bahan pangan baru mengingat besarnya ketergantunganmasyarakat Indonesia terhadap satu macam sumber karbohidrat saja.

Selain beras sebagai sumber karbohidrat banyak terdapat bahan pangan lainnyayang memiliki kandungan karbohidrat yang tinggi seperti umbiumbian.salah satunya jenis tumbuhan tersebut adalah ubi banggai yang terdapat di Kabupaten Banggai, kandungan nutrisinya adalahkarbohidrat 15-25\%, lemak 0,05-0,20\%, dan protein 1,0-2,5\% (Rostiaty, dkk 2002).

Ubi Banggai (Dioscorea sp) masih belum banyak digunakan sebagai produk olahan oleh masyarakat di Kab. Banggai Kepulauan dan sekitarnya sehingga belum banyak yang dikembangkan dalam skala besar.Ubi Banggai biasanya di konsumsi oleh masyarakat Banggai sebagai makanan ringan bukan sebagai makanan pokok. Pengolahan ubi Banggai untuk produk pangan baru perlu dikembangkan. Berdasarkan potensinyaubi Banggai dapat digunakan sebagai sumber makanan pengganti beras dalam skala yang lebih besar, dan dapat diolah sebagai produk makanan olahan.

Salah satu bentuk olahan makanan yang mudah dikonsumsi adalah bubur.Bubur memiliki tekstur yang lunak dan agak encer (tidak padat) sehingga mudah bagi konsumen untuk menikmatinya.Pengembangan produk baru berupa bubur instan dengan bahan dasar Ubi Banggai dilakukan sebagai salah satu bentuk pengolahan makanan cepat saji.

Kegunaan pembuatan bubur instan selain praktis untuk disajikan, buburinstan juga sudah mengalamipengolahan lebih lanjut tanpa mengurangi rasa dari bahan pokoknya. Bubur instan sudah banyak diproduksi di Indonesia seperti Super bubur berbahan dasar beras, bubur sargum, bubur singkong, tetapi yang diedarkan dipasaran hanya produk super bubur.

Ubi Banggai berdasarkan penelitian yang dilakukan oleh Siti Novalya memilik kandungan fenolat. Kandungan fenolat tersebut berbeda dengan satu dengan yang lain. Ubi Banggai ungu kandungan fenolatnya $2,43 \%$ sedangkan ubi putih $2,62 \%$. Senyawa fenolat mudah rusak bila dilakukan pemanasan, dimana gugus $\mathrm{OH}$ yang terikat pada cicin bensenakan teroksidasi. Berdasarkan ini, akan dilakukan penelitian untuk mengetahui seberapa besar kerusakan terjadi waktu dilakukan pengolahan menjadi bubur instan. 
Kualitas produk pangan tidak hanya diukur oleh nilai nutrisi, tetapi juga diukur oleh kualitas pendukung lainnya seperti tekstur, rasa dan aroma serta warna yang dikenal dengan uji sensori (organoleptik). Uji organoleptik ditentukan dari penilaian instrumen manusia $\mathrm{Uji}$ mutu sensori (organoleptik) dilakukanuntuk mengetahui tingkat penerimaan konsumen terhadap suatu produk.Uji fisik dan kimia serta uji gizi dapat menunjukkansuatu produk pangan bermutu tinggi, namun tidak akan ada artinya jikaproduk tersebut tidak dapat dikonsumsi karena tidak enak atau sifatorganoleptiknya tidak membangkitkan selera atau tidak dapat diterimakonsumen.

\section{METODE PENELITIAN}

\section{Bahan dan Peralatan}

Bahan yang digunakan dalam penelitian antara lain: ubi banggai jenis,air ,CMC, dekstrin,fenol murni, aquades, indikator metil orange (MO), asam fosfat, $\mathrm{NH}_{4} \mathrm{OH}$, buffer fosfat.

Alat yang digunakan dalam penelitian antara lain ;kompor, wajan, pisau, spektrum, labu ukur, erlenmeyer, kuvet, penangas air, neraca analitik, pipet volume, $\mathrm{pH}$ meter, dan alat-alat gelas lainnya

\section{Prosedur Penelitian}

\section{Pembuatan Bubur Instan}

Ubi Banggai dengan 2 jenis yang berbeda dikupas kulitnya,kemudian dipotong menjadi beberapa bagian, setelah itu mencucinya hingga bersih, dan dikukus selama 15 menit, dinginkan, lalu dihancurkan. Ubi yang telah dihancurkan ditambahkan air dengan perbandingan air dan ubi 4:1lalu ditambahkan CMC1\% dan dekstrin 15\%. Adonandimasak hingga kental (gelatinasi) dan didinginkan ( Ubi Banggai basah hasil glatinasi). Setelah didinginkan ubi dianalisis kadar fenolatnya,sebagian dikeringkan dengan panas matahari,seterusnya dihaluskan dan menjadi puree Ubi Banggai ( ubi Banggai kering hasil glatinasi)dan dianalisis kembali kadar fenolatnya, kemudian tepung ubi Banggai diseduh menggunakan air panas hingga mengental (Bubur instan) dan dianalisis kembali kadar fenolatnya.

\section{Penentuan kadar fenolat tepung ubi banggai (SNI dalam Leman. 2009)}

\section{a. Pembuatan kurva baku \\ Fenol murni ditimbang sebanyak $1 \mathrm{~g}$} kemudian dimasukkan kedalam gelas kimia dan ditambahkan aquades sekitar $100 \mathrm{ml}$, selanjutnya diaduk hingga semua fenol larut. Larutan fenol dipindahkan secara kuantitatif kedalam labu ukur 1 liter dan ditepatkan volumenya dengan aquades. Larutan fenol diambil dengan pipet volum, kemudian dimasukkan kedalam labu ukur $50 \mathrm{ml}$, dan ditepatkan volumenya dengan aquades. Larutan diencerkan untuk mendapatkan larutan standar fenol dengan konsentrasi 5 ppm, 10 ppm, 15 ppm, 20 ppm dan 25 ppm, dalam labu ukur $50 \mathrm{ml}$. Setiap larutan dipindahkan kedalam elenmeyer $\mathrm{ml}$ kemudian dipanaskan dalam penangas air selama 5 menit. Lalu ditambahkan 1-2 tetes indikator metil orange (MO) sampai terbentuk wrna 
kuning. Larutan selanjutnya ditambahkan 2-3 tetes asam fosfat $1: 9$ sampai terbentuk warna merah jingga. Larutan didinginkan kemudian ditambahkan 1,2 ml $\mathrm{NH}_{4} \mathrm{OH} 0,5 \mathrm{~N}$, kemudian diatur $\mathrm{pH}$ larutan hingga $7,9=0,1$ dengan buffer fosfat $(\mathrm{pH}=$ 12). Masing-masing larutan diukur serapannya pada panjang gelombang maksimum berdasarkan hasil pengukuran spektrum serapan larutan standar fenol 10 ppm. Hasil pengukuran serapan di plotkan dalam kurva hubungan antara absorban terhadap konsentrasi fenol untuk menghasilkan kurva baku.

b. Ekstraksi fenolat sampel (Wulandari,2011)

Tepung Ubi Banggai ditimbang $10 \mathrm{~g}$, kemudian dimasukkan kedalam elenmeyer dan ditambahkan etanol. Rasio etanol terhadap ubi Banggai 15 :1.kemudian di seiker diatas mesin agitasi 200 rpm selama 2 jam. Campuran disaring untuk mendapatkan ekstrak fenolat tepung ubi banggai.Ekstrak yang diperoleh dipekatkan secara vakum menggunakan rotary evaporator. Parameter yang diamati adalah kadar fenolat terhadap ubi banggai, perlakuan yang sama dilakukan terhadap ubi Banggai basah dan bubur ubi Banggai.

c. Analisis sampel

Ekstrak tepung ubi Banggai $10 \mathrm{ml}$ dimasukkan kedalam elenmeyer $100 \mathrm{ml}$ kemudian dipanaskan dalam penangas air selama 5 menit, lalu ditambahkan 1-2 tetes indikator metil orange (MO) sampai terbentuk warna kuning. Larutan selanjutnya ditambahkan 2-3 tetes asam fosfat $1: 9$ sampai terbentuk warna merah jingga. Larutan didinginkan kemudian $\begin{array}{llllll}\text { ditambahkan } & 1,2 & \mathrm{ml} & \mathrm{NH}_{4} \mathrm{OH} & 0,5 & \mathrm{~N}\end{array}$ kemudian diatur $\mathrm{pH}$ larutan hingga 7,9= 0,1 dengan buffer fosfat $(\mathrm{pH}=12)$. Sampel kemudian diukur pada panjang gelombang maksimum $460 \mathrm{~nm}$. Total fenolat sampel ditentukan dengan rumus :

$$
\% \text { fenolat }=\frac{X\left(\frac{\mathrm{mg}}{1000 \mathrm{ml}}\right) \times \text { volumesampel }(\mathrm{ml})}{\text { Bobot sampel }(\mathrm{mg})} 100 \%
$$

Ket: $\mathrm{X}=$ konsentrasi fenolat $(\mathrm{mg} / 1000 \mathrm{ml})$

\section{Uji Mutu Organoleptik}

Pengujian organoleptik bertujuan untuk membandingkan tingkat kesukaan panelis terhadap produk bubur ubi Banggaiinstan.Uji organoleptik yang digunakan adalah uji kesukaan (hedonik) terhadap atribut rasa, warna, tekstur dan aroma. Uji mutu hedronik ini menggunakan kisaran 1-7 untuk masing-masing atribut. Misalkan uji kesukaan nilai 1 = sangat tidak suka, 2 = tidak suka, 3 = agak tidak suka, 4 = netral, 5 = agak suka, $6=$ suka, $7=$ sangat suka. Pengujian dilakukan dengan dengan menggunakan 25 panelis mahasiswa Jurusan Kimia Universitas Tadulako, Palu. Selanjutnya dilakukan analisis uji $t$ untuk melihat perbandingan mutu organoleptik tiap parameter rasa, warna, aroma, dan tekstur masing-masing dari bubur instan ubi Baku Pukkus dan Baku Makulolong.

\section{HASIL DAN PEMBAHASAN}

\section{Kadar Fenolat total}

Penentuan kadar fenolat total, menggunakan fenol sebagai larutan 
standar. Menurut Novalya (2012), serapan maksimum fenol untuk analisis kadar fenolat ubi Banggi diperoleh pada panjang $460 \mathrm{~nm}$. Sebelum melakukan pengukuran kadar fenolat total, terlebih dahulu dibuat kurva baku larutan standar fenol dengan konsetrasi 5 ppm, 10 ppm, 15 ppm, 20 ppm, dan 25 ppm. Pembuatan kurva baku bertujuan untuk menentukan kadar fenol yang terdapat dalam sampel. Hasil pengukuran serapan pada berbagai larutan standar fenolseperti dengan persamaan regresi sebagai berikut $y=0,105 x+0,008$, koefesien korelasi $(r) 0,995$. Nilai $r$ yang mendekati 1 memberikan indikasi linearitas antara absorban dan konsetrasi cukup tinggi.

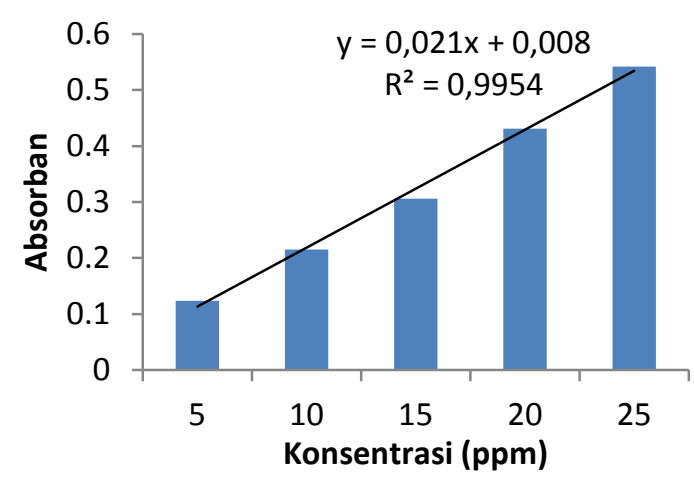

Gambar 1. Hasil pengukuran absorban larutan standar fenol pada panjang gelombang $460 \mathrm{~nm}$ dengan spektofotometer

Hasil analisis kadar fenolat dari sampel ubi Baku Pukus dan ubi Baku Makulolong (tabel lampiran4) menunjukkan bahwa dari kedua jenis ubi tersebut memiliki kadar fenolat berbeda-beda, baik dalam keadaan basah(hasil glatinasi), kering (hasil glatinasi) maupun saat menjadi bubur instan.

Ubi Banggai jenis Baku makulolong basah (hasil glatinasi) memiliki kadar fenolat 2,38 \% dan Baku Pukus basah (hasil glatinasi) memiliki kadar fenolat 2,16 $\%$.Baku Makulolong kering (hasil glatinasi) memiliki kadar fenolat1,63 \% dan Baku Pukus kering (hasil glatinasi) memiliki kadar fenolat 1,39 \%. Bubur Baku Makulolong kadar fenolatnya lebih tinggi dibandingkan kadarfenolat yang dimiliki Baku Pukus. Kadar fenolat yang terkandung pada bubur Baku Makulolong $1,85 \%$ dan kadar fenolat yang terkandung pada bubur Baku Pukus 1,67 \%.

Dari hasil yang didapatkan kadar fenolat semakin menurun. Hal ini disebabkan karena adanya pemanasan sehingga gugus $\mathrm{OH}$ yang terikat pada cicncin bensen akan teroksidasi yang mengakibatkan senyawa fenolat menjadi rusak

\section{Mutu Organoleptik}

Mutu organoleptik bubur instan dari Baku Pukus danBaku Makulolong dilihat dari parameter rasa, warna, aroma dan tekstur. Penilaian daya terima warna, aroma, tekstur, dan rasa menggunakan uji hedonik dengan tujuh skala kesukaan yaitu 1=Sangat Tidak Suka, 2=Tidak Suka, 3=Agak Tidak Suka, 4=Netral, 5=Agak suka, 6=Suka, dan 7=Sangat Suka. Penilaian daya terima dilakukan pada 25kelompok (panelis).Dan analisa perbandingan dari parameter rasa, warna, 
tekstur, dan aroma dengan menggunakan rumus $t$.

\section{a. Rasa}

Hasil mutu organoleptik terhadap rasa pada bubur instan Baku Pukus dan bubur instan Baku Makulolong dapat dilihat pada gambar di bawah ini.

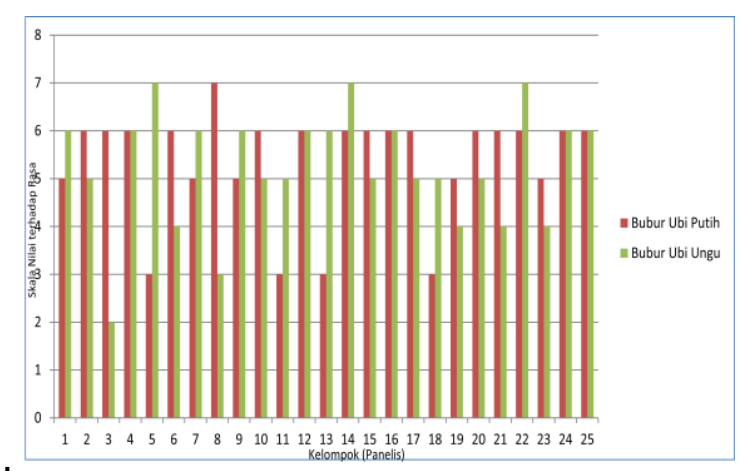

Ket : Skala nilai: 1 = sangat tidak suka, 2 = tidak suka, 3 = agak tidak suka, 4 = netral, $5=$ agak suka, $6=$ suka, $7=$ sangat suka.

\section{Gambar 2. Tingkat kesukaan kelompok/} Panelis terhadap parameter rasa

Dari hasil uji mutu organoleptik pada parameter rasa, menunjukkan bahwa tingkat kesukaan kelompok (panelis) terhadap rasa bubur instan Baku Pukus putih rata-rata 3 . Hal ini berarti bahwa tingkat kesukaan kelompok (panelis) terhadap rasa bubur instan Baku Pukus dinilai agak tidak suka. Adapun tingkat kesukaan kelompok (panelis) terhadap rasa bubur instan Baku Makulolong ratarata 2,72 . Hal ini berarti bahwa tingkat kesukaan kelompok (panelis) terhadap rasa bubur instan Baku Makulolong dinilai cenderung agak tidak suka.

Adapun hasil uji mutu organoleptik yang dilakukan oleh Hendy (2007) terhadap parameter rasa menunjukkan tingkat kesukaan panelis terhadap rasa bubur instan singkong adalah tidak suka.Analisa perbandingan mutu organoleptik terhadap parameterrasa antara bubur instan dari Baku Pukus dengan bubur instan dari Baku Makulolong dapat dilihat pada tabel lampiran 6 .

Dari hasil analisa tersebut menunjukkanbahwa nilai statistik $t$ yang diperoleh adalah 1.649, dan nilai $p$-value pengujian adalah 0,548. Dengan menggunakan kaidah pengambilan keputusan berdasarkan $p$-value, maka pada $\alpha=0.05$ dapat disimpulkan bahwa pengujian menunjukkan gagal, tolak Ho. Dengan demikian dapat dijelaskan bahwa rata-rata tingkat kesukaan panelis pada bubur instan Baku Pukus dengan Baku Makulolongadalah tidakberbeda.Atau tidak ada perbedaan yang nyata $(P>0,05)$ antara tingkat kesukaan kelompok (panelis) terhadap rasa bubur instan Baku Pukus dengan Baku Makulolong.

b. Warna

Dalam uji organoleptik, pertama kali suatu produk dinilai dengan menggunakan mata yaitu dengan melihat warna yang dimiliki.Biasanya banyak sifat komoditi produk yang berkaitan dengan warna. Setelah melihat warna akan muncul ketertarikan karena warna berkaitan dengan cita rasa suatu produk. Selain itu, warna juga dapatdigunakan sebagai indikator kesegaran atau kematangan, baik tidaknyacara pencampuran atau cara pengolahannya (Apriliyanti, 2010). 
Menurut Kartika (dalam Apriliyanti, 2010) warna merupakan suatu sifat bahanyang berasal dari penyebaran spektrum sinar, begitu juga kilap dari bahanyang dipengaruhi oleh sinar pantul. Warna bukan merupakan suatu zatatau benda melainkan sensasi sensori seseorang karena adanya rangsangandari seberkas energi radiasi yang jatuh ke indera penglihatan.Apabilasuatu bahan pangan atau produk mempunyai warna yang menarik dapatmenimbulkan selera seseorang untuk mencoba produk tersebut karenawarna merupakan salah satu profil visual yang menjadi kesan pertama konsumen dalam menilai suatu produk. Fennema (dalam Apriliyanti, 2010) menambahkan,warna adalah atribut kualitas yang paling penting. Bersamasama dengantekstur dan rasa, warna berperan dalam penentuan tingkat penerimaankonsumen terhadap suatu produk, meskipun produk tersebut bernilai gizitinggi, rasa enak dan tekstur baik namun jika warna tidak menarik makaakan menyebabkan produk tersebut kurang diminati.

Hasil uji mutu organoleptik pada parameter warna dapat dilihat pada Gambar 3.

Dari hasil uji mutu organoleptik pada parameter warna, menunjukkan bahwa tingkat kesukaan kelompok (panelis) terhadap warna bubur instan Baku Makulolong rata-rata 4,8. Hal ini berarti bahwa tingkat kesukaan kelompok (panelis) terhadap warna bubur instan
Baku Pukus dinilai cenderung agak suka. Adapun tingkat kesukaan kelompok (panelis) terhadap warna bubur instan Baku Makulolong rata-rata 5,6. Hal ini berarti bahwa tingkat kesukaan kelompok (panelis) terhadap warna bubur instan Baku Makulolong dinilai cenderung suka.

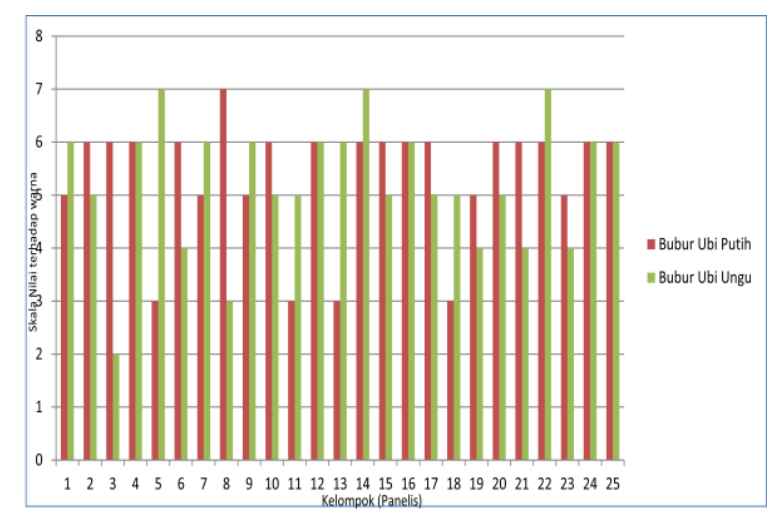

Ket : Skala nilai: 1 = sangat tidak suka, $2=$ tidak suka, 3 = agak tidak suka, $4=$ netral, 5 = agak suka, $6=$ suka, 7 = sangat suka.

Gambar 3. Tingkat kesukaan panelis dalam parameter warna

Adapun hasil uji mutu organoleptik yang dilakukan oleh Hendy (2007) terhadap parameter parameter warna menunjukkan tingkat kesukaan terhadap warna bubur instan singkong adalah agak suka.

Hasil uji mutu organoleptik parameter warna yang dilakukan Tina Apriliyanti (2010), diketahui bahwa proses pengeringandengan Kabinet Dryer $\mathrm{T} 50 \mathrm{oC}$ Tidak Blanching dan Kabinet Dryer T60oCTidak Blanching lebih disukai warnanya dari pada tepung ubi jalar ungu denganproses pengeringan yang lain.

Adapun analisa perbandingan mutu organoleptik terhadap parameter warna antara bubur instan dari Baku Pukus 
dengan bubur instan dari Baku makulolong dapat dilihat pada tabel lampiran 6 .

Dari hasil analisa tersebut menunjukkan bahwa nilai statistik $t$ yang diperoleh adalah $-2,060$, dan nilai $p$-value pengujian adalah 0,045. Dengan menggunakan kaidah pengambilan keputusan berdasarkan p-value, maka pada $\alpha=0.05$ dapat disimpulkan bahwa pengujian menunjukkan tidak gagal, terima Ho. Dengan demikian dapat dijelaskan bahwa rata-rata tingkat kesukaan kelompok (panelis)terhadap warnabubur instan Baku Pukus dengan Baku Makulolong adalah berbeda.Atau ada perbedaan yang nyata $(P<0,05)$ antara tingkat kesukaan kelompok (panelis) terhadap warna bubur instan Baku Pukus dengan Baku Makulolong. Kelompok (panelis) lebih suka bubur instan Baku Makulolong dibandingkan bubur instan Baku Pukus.

\section{c. Tekstur}

Tekstur bahan pangan merupakan kumpulan dari sejumlah karakter yang bebeda, yang dirasakan oleh bermacammacam anggota tubuh manusia (Apriliyanti, 2010). Kartika (dalam Apriliyanti, 2010) menyatakan tekstur merupakan sensasi tekanan yang dapat diamati dengan menggunakan mulut (pada waktu digigit, dikunyah, dan ditelan), ataupun dengan perabaan dengan jari.

Dari hasil uji mutu organoleptik pada parameter tekstur, menunjukkan bahwa tingkat kesukaan kelompok (panelis) terhadap tekstur bubur instan Baku Pukus rata-rata 5,36 . Hal ini berarti bahwa tingkat kesukaan kelompok (panelis) terhadap aroma bubur instan Baku Pukus dinilai agak suka. Adapun tingkat kesukaan kelompok (panelis) terhadap tekstur bubur instan Baku Makulolong rata-rata 5,28. Hal ini berarti bahwa tingkat kesukaan kelompok (panelis) pada tekstur bubur instan Baku Makuloolong dinilai agak suka.

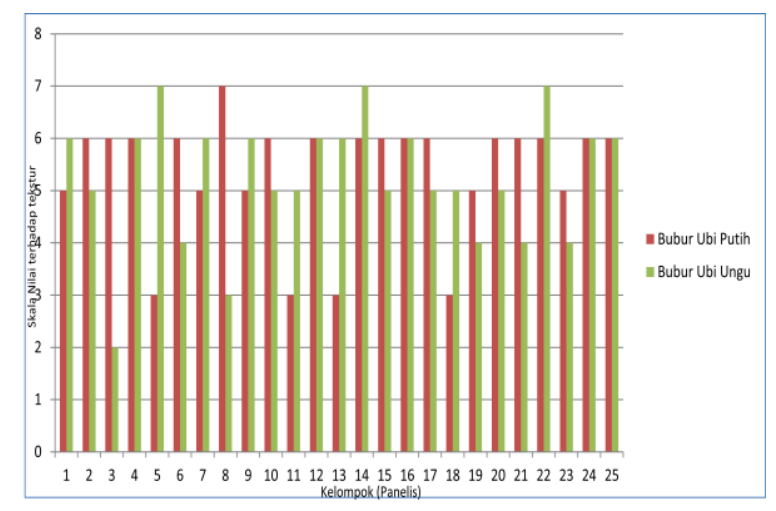

Ket: Skala nilai: 1 = sangat tidak suka, 2 = tidak suka, 3 = agak tidak suka, 4 = netral, 5 = agak suka, $6=$ suka, 7 = sangat suka.

Gambar 4. Tingkat kesukaan Kelompok/ Panelis terhadap parameter tekstur

Hasil uji Mutu organoleptik yang dilakukan pada bubur instan singkong menunjukkan tingkat kesukaan panelis terhadap tekstur bubur instan singkong adalah netral (Hendy:2007)

Dari hasil analisa organoleptik menunjukkan bahwa nilai statistik $t$ yang diperoleh adalah 0,476 , dan nilai $p$-value pengujian adalah 0,636. Dengan menggunakan kaidah pengambilan keputusan berdasarkan p-value, maka pada $\alpha=0.05$ dapat disimpulkan bahwa pengujian menunjukkan gagal, tolak Ho. Dengan demikian dapat dijelaskan bahwa rata-rata tingkat kesukaan kelompok 
(panelis) terhadap tekstur bubur instan Baku Pukus dengan Bakumakulolong adalah tidak berbeda. Atau tidak ada perbedaan yang nyata antara tingkat kesukaan kelompok (panelis) terhadap tekstur bubur instan Baku Pukus dengan Baku Makulolong

\section{d. Aroma}

Aroma dapat didefinisikan sebagai sesuatu yang dapatdiamati dengan indera pembau. Untuk menghasilkan bau, zat-zat bau harus dapat menguap, sedikit larut dalam air dan sedikit dapat larut dalam lemak. Di dalam industri pangan, pengujian terhadap bau dianggap penting karenadengan cepat dapat memberikan hasil penilaian terhadap produk tentang diterima atau tidaknya produk tersebut. Selain itu, bau dapat dipakai juga sebagai suatu indikator terjadinya kerusakan pada produk (Aprilianti:2010). Cita rasa dan aroma timbul karena adanya senyawa kimia alamiah maupun sintetik dan reaksi senyawa tersebut dengan ujung-ujung syaraf indera lidah dan hidung. Bau makanan banyak menentukan kelezatan bahan pangan tersebut. Dalam hal bau lebih banyak sangkut-pautnya dengan alat panca indera penghidung (Winarno, 2989).

Menurut de Mann (1989), dalam industri pangan pengujian aroma atau bau dianggap penting karena cepat dapat memberikan hasil penilaianterhadap produk terkait diterima atau tidaknya suatu produk. Timbulnya aroma atau bau ini karena zat bau tersebut bersifat volatile (mudah menguap), sedikit larut air dan lemak.

Hasil uji mutu organoleptik pada parameter aroma dapat dilihat pada gambar di bawah ini.

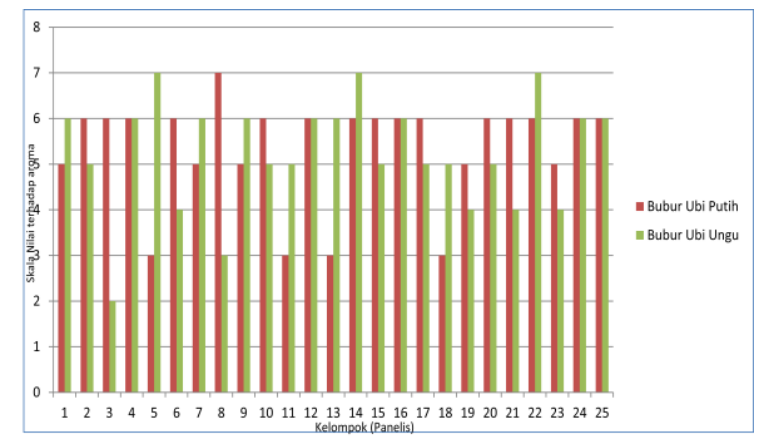

Ket: Skala nilai: 1 = sangat tidak suka, 2 = tidak suka, 3 = agak tidak suka, 4 = netral, 5 = agak suka, 6 = suka, 7 = sangat suka.

Gambar 5. Tingkat kesukaan Kelompok/ Panelis terhadap parameter aroma

Dari hasil uji mutu organoleptik pada parameter aroma, menunjukkan bahwa tingkat kesukaan kelompok (panelis) terhadap aroma bubur instan Baku Pukus rata-rata 3,04. Hal ini berarti bahwa tingkat kesukaan kelompok (panelis) terhadap aroma bubur instan Baku Pukus dinilai agak tidak suka. Adapun tingkat kesukaan kelompok (panelis) terhadap aroma bubur instan Baku Makulolong rata-rata 2,8. Hal ini berarti bahwa tingkat kesukaan kelompok (panelis) pada aroma bubur instan Baku makulolong dinilai cenderung agak tidak suka.

Hasil uji mutu organoleptik pada bubur instan singkong menunjukkan bahwa tingkat kesukaan panelis terhadap aroma bubur instan singkong adalah netral (Hendy, 2007) 
Hasil analisa perbandingan mutu organoleptik terhadap parameteraroma antara bubur instan dari Baku Pukus dengan bubur instan dari Baku Makulolong dapat dilihat pada tabel lampiran 8 .

Dari hasil analisa tersebut menunjukkan bahwa nilai statistik t yang diperoleh adalah 0,483 , dan nilai $p$-value pengujian adalah 0,630. Dengan menggunakan kaidah pengambilan keputusan berdasarkan $p$-value, maka pada $\alpha=0.05$ dapat disimpulkan bahwa pengujian menunjukkan gagal, tolak Ho. Dengan demikian dapat dijelaskan bahwa rata-rata tingkat kesukaan kelompok (panelis) terhadap aroma bubur instan Baku Pukus dengan Baku Makulolong adalah tidakberbeda. Atau tidak ada perbedaan yang nyata $(P>0,05)$ antara tingkat kesukaan kelompok (panelis) terhadap aroma bubur instan Baku Pukus dengan Makulolong.

\section{KESIMPULAN}

Hasil analisis kadar fenolat dari sampelBaku Pukus basa (hasil glatinasi) 2,16\%, Baku Makulolong basah (hasil glatinasi) 2,37 \%, Baku Pukus kering (hasilGlatinasi) 1,89\%, Baku Makulolong kering (hasil Glatinasi) 1,65 \% dan bubur instanBaku Makulolongmemiliki kadar fenolat $1,84 \%$ dan kadar fenolat yang terkandung pada bubur instan Baku Pukus $1,56 \%$.
Dari hasil uji mutu organoleptik pada parameter rasa, aroma dan tekstur menunjukkan bahwa tidak ada perbedaan yang nyata antara bubur instan ubi putih dengan bubur instan ubi ungu. Sedangkan pada parameter warna menunjukkan adanya perbedaan nyata antara warna bubur instan Baku Pukus dengan bubur instan Baku makulolong. Maka diperlukan adanya penelitian lebih lanjut tentang mutu organoleptik dan kadar gizi bubur instan pada berbagai varietas ubi Banggai.

\section{DAFTAR PUSTAKA}

Aprilianti, T. 2010. Kajian sifat fisikokimia dan sensori tepung ubi jalarUngu (ipomoea batatas blackie) dengan variasi proses pengeringan. [Skripsi]. Surakarta: Fakultas Pertanian Universitas Sebelas Maret.

Hendy. 2007. FormulasiBubur Instan Berbasis Singkong.

Novalya, S. 2012. Kajian Kandungan Fenolat dari Berbagai Varietas Ubi Banggai. [Skripsi]. Palu: Jurusan Kimia Fakultas Matematika dan IImu Pengetahuan Alam Universitas Tadulako.

Rostiati, R. L., Alam. N., Murhadi, Rahmadanil, Sangadji, M. N. 2002. Pengolahan Pasca Panen Ubi Banggai, Kajian Dari Karakteristik Tepung Ubi Banggai.. Palu: Lembaga Penelitian Universitas Tadulako.

Winarno, F. G., 1989. Kimia Pangan dan Gizi. Jakarta: Penerbit Gramedia.

Wulandari, S. A. 2011. Ekstrak dan Analisis Kandungan Fenolat Ekstrak Etanol Kulit Ari Biji kakao (Theobroma cacao, L). [Skripsi]. Palu: Program Studi Kimia FMIPA Universitas Tadulako. 